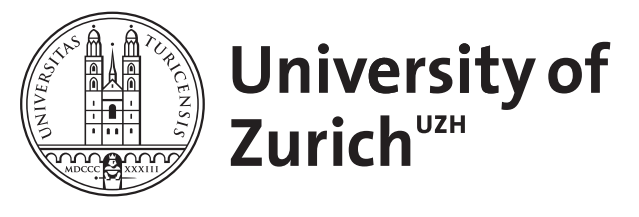

\title{
Morphological convergence in conifer-dwelling passerines
}

Korner-Nievergelt, F ; Leisler, B

\begin{abstract}
We tested for morphological convergence in conifer specialists among 88 passerines belonging to seven different phylogenetic lineages by discriminant factor analysis. We found a parallel trend among the seven lineages in body mass and digital pad morphology, whereas no such trends existed for the feeding and flight apparatus. Compared to the control species, the conifer specialists have smaller body masses and higher digital pads with maximal widths lying more distally within each of the seven lineages. These traits are interpreted as adaptations to dwelling among coniferous needles
\end{abstract}

DOI: https://doi.org/10.1007/s10336-004-0027-8

Posted at the Zurich Open Repository and Archive, University of Zurich ZORA URL: https://doi.org/10.5167/uzh-155843

Journal Article

Published Version

Originally published at:

Korner-Nievergelt, F; Leisler, B (2004). Morphological convergence in conifer-dwelling passerines. Journal of Ornithology, 145(3):245-255.

DOI: https://doi.org/10.1007/s10336-004-0027-8 


\section{Morphological convergence in conifer-dwelling passerines}

Received: 19 January 2004 / Revised: 9 February 2004/ Accepted: 9 February 2004 / Published online: 13 March 2004 (C) Dt. Ornithologen-Gesellschaft e.V. 2004

\begin{abstract}
We tested for morphological convergence in conifer specialists among 88 passerines belonging to seven different phylogenetic lineages by discriminant factor analysis. We found a parallel trend among the seven lineages in body mass and digital pad morphology, whereas no such trends existed for the feeding and flight apparatus. Compared to the control species, the conifer specialists have smaller body masses and higher digital pads with maximal widths lying more distally within each of the seven lineages. These traits are interpreted as adaptations to dwelling among coniferous needles.
\end{abstract}

Keywords Coniferous specialists · Ecomorphology · Morphological convergence - Multivariate analysis · Passerines

\section{Introduction}

The hypothesis of convergence states that under similar environmental conditions, species have become more similar in certain characteristics than their ancestors (Schluter 1986). Such similarities, e.g. in morphology, are caused by common selection pressures (Grant et al. 1976; Cody and Mooney 1978; Futuyma 1998). This is an extension of the more general hypothesis that morphological characteristics of organisms are predictable from features of their environment (Hespenheide 1973;

Communicated by: F. Bairlein

F. Korner-Nievergelt $(\bowtie)$

Zoological Museum, University Zurich,

Winterthurerstr. 190, 8057 Zurich, Switzerland

E-mail: fraenzi.korner@bluewin.ch

B. Leisler

Forschungsstelle für Ornithologie der Max-Planck Gesellschaft, Vogelwarte Radolfzell, 78315 Radolfzell, Germany
Karr and James 1975; Leisler and Winkler 1991; Ricklefs and Miles 1994).

Convergence should be particularly widespread in groups of animals which are morphologically constrained, e.g. by the requirement of flight as in birds, (Sibley and Ahlquist 1983). Ecomorphological studies in birds have demonstrated that subtle differences in shape of external morphology can have profound ecological effects (Leisler and Winkler 1985, 2001, 2003).

Here we examine possible morphological convergence of passerines living in conifers, adopting a relatively general view of convergence that also includes parallelism (Futuyma 1998). Specifically, we investigate whether a special habitat, i.e. the outermost twigs of temperate conifers (Pinus, Picea, Abies, Tsuga, Larix and Pseudotsuga), has induced the convergence of traits. This microhabitat is inhabited by bird species from seven different phylogenetic lineages. Each lineage is defined by one genus (Sitta, Parus, Regulus, Phylloscopus, Carduelis and Carpodacus), except that we consider two closely related genera (Dendroica and Parula) as one lineage (Parulidae). Within each lineage, we compare the conifer specialists with congeneric species inhabiting various other habitats.

So far, the relationship between morphology and coniferous habitat has only been compared within genera and has often yielded contradictory results. Within 16 Dendroica warblers of North America, the coniferous forest breeders are generally larger than deciduous forest breeders (Greenberg 1979). In contrast, among the Old World Phylloscopus warblers, the conifer-dwelling species have significantly lower body masses than the deciduous inhabitants (Gaston 1974; Forstmeier et al. 2001).

Considering the relationship of shape variables and life style we had the following expectations for each of the three functional complexes (feeding apparatus, flight apparatus, and hind limb):

1. A narrow and long bill is an adaptation to probing between needles, as suggested for the golden-crowned 
kinglet (Regulus satrapa; Keast and Saunders 1991), and for conifer-dwelling tits (Suhonen et al. 1994).

2. Long and pointed hand wings, broad arm wings and a deeply forked tail characterise frequently hovering species (Norberg 1990). We expect needle-dwellers to be adapted to hovering, because bipedal locomotion is impeded by needles. Increased frequencies of hovering have been shown for coniferous Phylloscopus warblers (Gaston 1974).

3. Two different extremes of locomotion types might induce two different morphological adaptations in the hind limb. Strong, well curved claws are expected for species that use their feet like pliers while gripping twigs or a bundle of needles, or while hooking into cones. Thereby, the centre of the body often hangs upside down, below the contact points of the substrate and the feet. This locomotion type is described for coal tits (Parus ater) by Löhrl (1974). On the other hand, plantar integument that provides high friction on thin, smooth structures, and large feet and legs are needed by those birds that cling to the substrate in order to maintain an upright position of the body (Leisler et al. 1989; Winkler and Bock 1976). This locomotion type is typical in thin vertical structures, as for example in reeds (reed warblers Acrocephalus sp.; Leisler et al. 1989). A similar locomotion type has been described for the needledwelling goldcrest (Regulus regulus; Leisler and Thaler 1982). These authors assumed that high friction could be achieved by elevated digital pads.

The objective of this study is to determine the degree of morphological convergence in birds that forage in the outermost twigs of conifers by comparing the morphology among and within lineages.

\section{Methods}

Species and specimens

We looked world wide for passerines that forage in the outermost twigs of conifers, and which have one or more congeneric species with a different ecology. We found 28 such species, which we refer to as "needle-dwellers". The congeneric "control species" were selected so that the entire ecological spectrum of each genus was represented in the sample. In order to achieve such a selection, we first defined 13 habitat types that were used for foraging (Table 1). Then, we assigned each congeneric species of each needle-dweller to one or more foraging habitat types. From each genus, we then selected at least one species from each habitat type. If possible, we discarded the rare species. Finally, we added one to three species that showed the most genus-typical foraging habitat. In total, we selected 88 species (Appendix), among them 28 needle-dwellers and 60 control species.

In total, 656 specimens were measured, with an average of seven specimens per species (Appendix). In each species, the sexes were about equally represented.

The study skins were kindly provided by Anatoly Shapoval (private collection, Rybachy), the British Museum of Natural History, Tring, Museum Alexander Koenig, Bonn, Museum für Naturkunde, Berlin, Natural History Museum, Bern, Natural History Museum, Basel, and the Zoological Museum of the University of Zurich.
Table 1 Bird foraging habitat types used for the species selection

\begin{tabular}{ll}
\hline Code & Description \\
\hline 1 & Coniferous needles, foliage of conifers (i.e. Pinacea) \\
2 & Coniferous twigs, canopy of conifers (i.e. Pinacea) \\
3 & Tree trunk \\
4 & Deciduous foliage \\
5 & Deciduous twigs, canopy of deciduous trees \\
6 & Tree foliage, deciduous or coniferous \\
7 & Tree canopy, deciduous or coniferous \\
8 & Bushes \\
9 & Herbs, grass \\
10 & Ground, sand, steppe \\
11 & Rock \\
12 & Reed \\
13 & Air \\
\hline
\end{tabular}

Morphological measurements

The study skins were relaxed in airtight boxes which contained pieces of leaves of cherry laurel (Prunus laurocerasus; Wechsler et al. 2001). The gas escaping from these leaves contains cyanogenic glycosides that soften dried organic parts.

The following external measurements were taken from the softened skins. From the feeding apparatus: (1) bill length (from the skull), (2) maximum bill depth, (3) maximum bill width (at the gape), (4) maximum length of rictal bristles; from the flight apparatus: (5) length of primary 8 , (6) length of primary $10,(7)$ primary projection (distance from the wing tip to the outermost secondary), (8) distance from the wrist to the tip of 5th secondary, (9) distance from the tip of the alula to the wing tip, (10) distance from the tip of primary 10 to the wing tip, (11) wing length, (12) emargination of the outer web of primary 8, (13) tail length, (14) depth of tail fork (tip to innermost tail feather), (15) graduation (tip to outermost tail feather); from the hind limb: (16) tarsus length, (17) tarsus width, (18) tarsus depth, (19-22) length of digits I to IV (without claws), (23-26) claw length I-IV, (27) curvature of claw I, (28) maximum width of the proximal pad on digit I, (29) length of the proximal pad on digit I, (30) height of the proximal digital pad on digit I, (31) position of max. width in percent of the pad length, (32) foot span without claws, and (33) number of papillae on the proximal pad on digit I.

For the curvature of the claw (27), photographs showing a side view of the hind toe were taken, printed, and the circle formed by the outer edge of the claw was drawn by hand. Then, the angle spanned by the claw was measured in degrees (Feduccia 1993). For counting the number of papillae on the proximal pad on digit I (33), we used a magnifying glass $(10 \times)$. All measurements were done by the same person (F.K.). In order to capture the amount of variance caused by measurement errors, we measured a selection of characters three times and calculated the percent measurement errors of the variance (Bailey and Byrnes 1990). The proportion of variance caused by measurement error ranged from $2.5 \%$ (length of primary 10 ) to $12.5 \%$ (length of the proximal pad on digit I) of the total variance. These errors of individual measurements can be neglected, since species means of each measurement were used for the study.

We used body masses given in Dunning (1992) and complemented them by the handbooks given in the Appendix. For the Vietnamese greenfinch (Carduelis monguilloti), we did not find any information on body mass; therefore we estimated its body mass by the regressions of body mass on wing and tarsus length for the other Carduelis species.

Statistical analysis

Data transformation

All lengths were corrected for body size by dividing them by the cube root of body mass (Leisler and Winkler 1991). In order to 
assess the sensitivity of the analysis to the method of size-correction, we performed all analyses with standardised residuals from the regression of each variable on the logarithm of body mass, as well as with uncorrected variables. The results were the same for all three variable treatments. After the size correction we ln-transformed the variables. We used the arcsine square root transformation for the curvature of the claw (27) and the position of the maximum width of the proximal pad on digit I (31). Finally, the number of papillae (33) was divided by the square of the cube root of body mass and root transformed. Body mass itself was lntransformed. The Q-Q-plots of the transformed variables showed no large deviation from the normal distribution.

\section{Variable reduction}

In order to avoid meaningless significances, the number of variables should not exceed one third of the sample size. Furthermore, the result of the discriminant factor analysis can be strongly affected if the variables are correlated. Therefore, we reduced the number of variables by omitting the ones that had similar loadings in principal component analysis performed for related subsets of the variables separately (Fig. 1). Variables that build clusters in the loading plots can be interpreted as being correlated or redundant. Therefore, only one variable of such a cluster was retained for analysis. In this way, we discarded seven variables: distance from the wing tip to the distance of the alula (9), distance from wing tip to primary $10(10)$, length of primary 8 (5), digit 4 (22), foot span (32) and claw 2 and 4 $(24,26)$. The remaining 27 variables were used for the further analysis.

\section{Discriminant function analysis}

The ecomorphological analysis of convergence involved two discriminant factor analyses (DFA) on SPSS 8.00 for Windows. First, we separated the phylogenetic lineages from each other, while in the second, the needle-dwellers were separated from the control species. The first DFA was performed to characterise the morphological differences which are due to phylogenetic origin and due to adaptations common to the species within each genus. The aim of the second DFA was to find morphological traits, which characterise needle-dwellers over all seven phylogenetic lineages. Therefore, such traits would indicate convergence. For both analyses, we used a stepwise model selection minimising Wilk's lambda, which is the ratio of the within-group sum of squares to the total sum of squares. In order to test the discriminant functions for robustness, we performed cross-validations, in which species are omitted one at a time before recalculating the discriminant functions. Additionally, we performed a randomisation test for the discrimination between needle-dwellers and control-species by splitting the species 999 times randomly into two groups, keeping the ratio between the groups in each lineage equal to the ratio between needle-dwellers and control-species in our sample. From every randomly grouped sample, we calculated the discriminant functions, as we did for the original sample. Based on these discriminant functions, we calculated the standard distances (distance between the two means divided by the standard deviation) between each of the 999 pairs of random groups. From the distribution of these standard distances we obtained the probability of the observed standard distance (between needle-dwellers and control species). This test gives the probability for the null hypothesis that the observed difference

Fig. 1 Loading plots for the first two principal components: a of the wing measurements (PC 1: $\lambda=4.499,56.23 \%$ of variance; $\mathrm{PC} 2$ : $\lambda=2.789,34.86 \%$ of variance), $\mathbf{b}$ of digit lengths and foot span (PC 1: $\lambda=4.789,59.56 \%$ of variance; PC $2: \lambda=1.239,15.49 \%$ of variance), and $\mathbf{c}$ of claw lengths (PC 1: $\lambda=3.696,92.40 \%$ of variance; PC 2: $\lambda=0.151,3.77 \%$ of variance). Measurements that are correlated lie close together. Numbers correspond to the measurements described in the Methods section

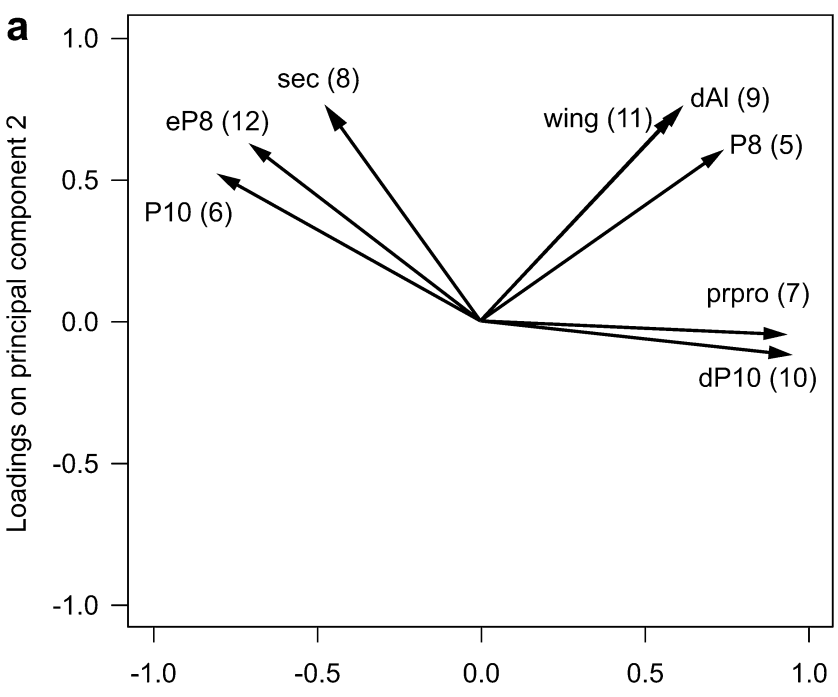

Loadings on principal component 1

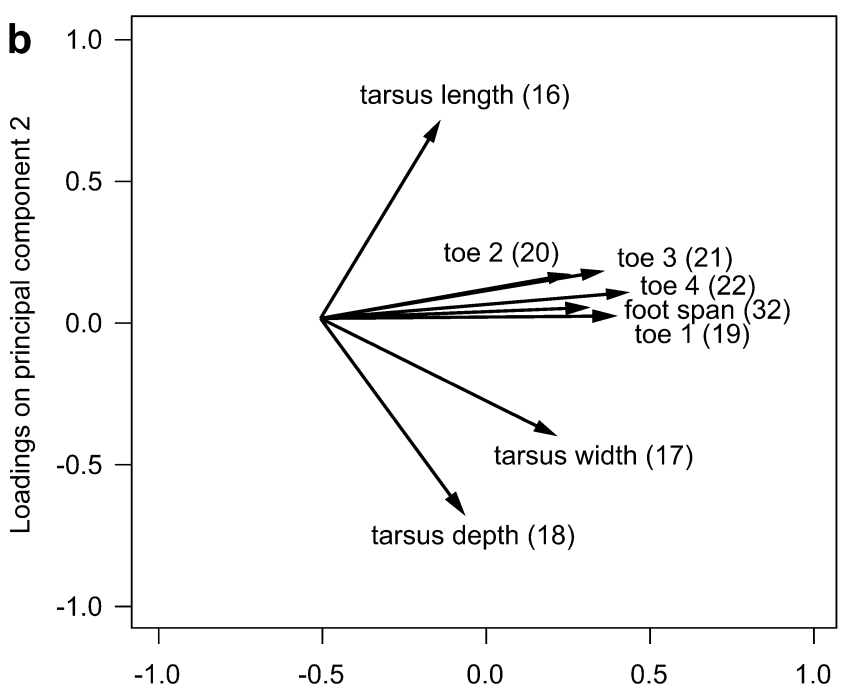

Loadings on principal component 1

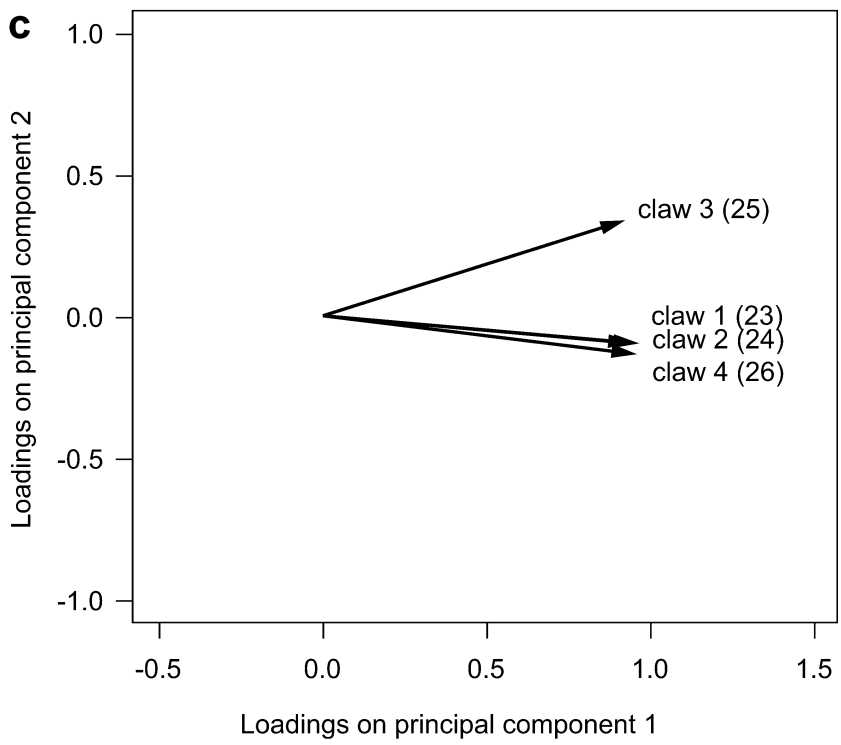

Loadings on principal component 1 
between our groups is a random effect. The randomisation test was performed on R 1.5 (R Development Core Team 2002). In this test, the number of degrees of freedom is too high, since all the 88 species contribute to it, instead of only the seven phylogenetic lineages or the about 20 pairs of sister species containing one needle-dweller and one control species. This might cause that biologically meaningless differences become statistically significant. On the other hand, by combining seven distantly related genera in one analysis, only the largest and therefore biologically most meaningful differences will be detected. We have therefore accepted a number of degrees of freedom which is too high.

\section{Results}

The separation of the seven lineages fully succeeded with six discriminant functions $(P<0.001$ for all six functions). $100 \%$ of the species can be correctly grouped, $98.9 \%$ by the cross-validated discriminant functions. The first two discriminant functions account for $82.2 \%$ of the variance (52.2 and $30.3 \%$, respectively). The species scores for these two discriminant functions are shown in Fig. 2. Eleven variables significantly contribute to the discrimination of the phylogenetic lineages (Table 2). Second DFA separated the needle-dwellers from the control species (Wilk's lambda $=0.78, d f=3$, $P<0.001)$. This discriminant function contains the variables that commonly characterise the needle-dwellers in our sample. $73.9 \%$ of the species can be grouped correctly by the discriminant function, and $71.6 \%$ by the cross-validated functions. Three variables significantly contribute to the discrimination, namely the position of the maximal width on the large pad on the hind toe, the height of this pad, and the body mass (Table 3). The standard distance between needle-dwellers and the control species is 1.116 , which is exceeded by only 27 of the 999 random samples (Fig. 3). In conclusion, our

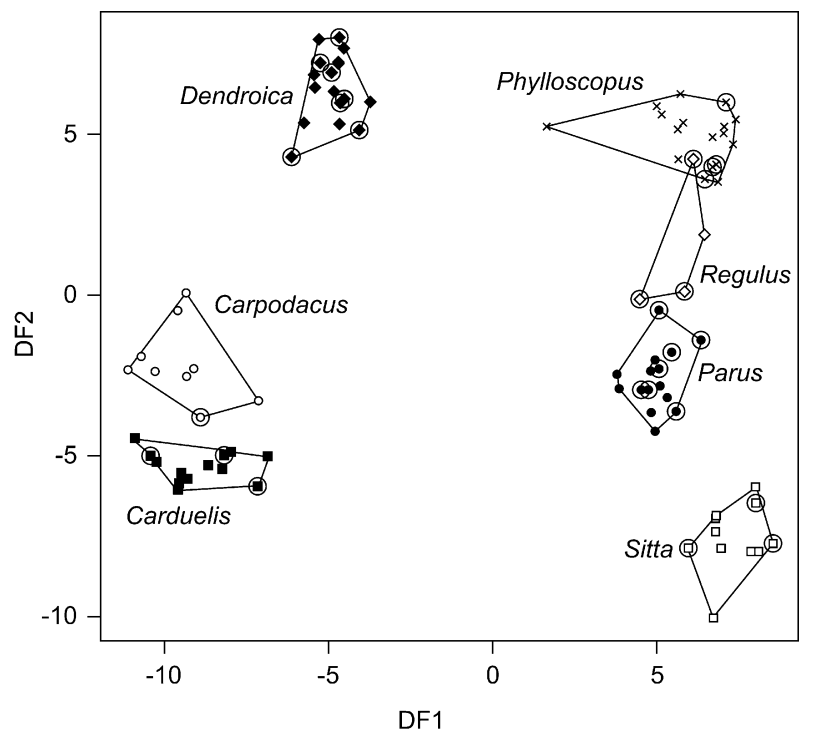

Fig. 2 Scatterplot of the species scores for the first two discriminant functions that separate the taxonomic lineages from each other. Large circle needle-dweller
Table 2 Discrimination of the lineages: Standardised canonical discriminant function coefficients (first number) and within-groups correlations between the variables and the discriminant functions (second number) for the first two discriminant functions. Significant ones are in bold. The variables are ordered as they entered into the discriminant functions

\begin{tabular}{lllll}
\hline Variable & \multicolumn{2}{l}{$\begin{array}{l}\text { Discriminant } \\
\text { factor 1 }\end{array}$} & \multicolumn{3}{c}{$\begin{array}{c}\text { Discriminant } \\
\text { factor 2 }\end{array}$} \\
\hline Length of primary 10 (6) & 0.93 & $\mathbf{0 . 7 9}$ & -0.29 & -0.13 \\
Tarsus length (18) & -0.10 & 0.24 & 0.77 & $\mathbf{0 . 4 4}$ \\
Length of pad (29) & -0.18 & -0.01 & 0.15 & $\mathbf{0 . 4 1}$ \\
Depth of tail fork (14) & -0.22 & -0.18 & -0.12 & -0.13 \\
Bill length (1) & 0.19 & 0.18 & 0.28 & 0.14 \\
Number of papillae (33) & 0.14 & 0.01 & 0.44 & $\mathbf{0 . 4 7}$ \\
Bill depth (2) & -0.55 & -0.34 & -0.40 & -0.27 \\
Length of hind toe (19) & 0.22 & 0.19 & -0.46 & -0.11 \\
Length of hind claw (23) & -0.11 & 0.16 & -0.48 & -0.17 \\
Tail length (13) & -0.12 & 0.02 & 0.32 & 0.19 \\
Width of pad (28) & -0.02 & -0.02 & 0.01 & 0.12 \\
\hline
\end{tabular}

Table 3 Discrimination of needle-dwellers from the controlspecies: Standardised canonical discriminant function coefficients and within-groups correlation between the variables and the discriminant function. Significant ones are in bold. The variables are ordered as they entered into the discriminant functions

\begin{tabular}{lll}
\hline Variable & $\begin{array}{l}\text { Standardised } \\
\text { coefficients }\end{array}$ & $\begin{array}{l}\text { Correlation with } \\
\text { discriminant function }\end{array}$ \\
\hline $\begin{array}{l}\text { Body mass } \\
\begin{array}{l}\text { Position of max. } \\
\text { width on toe pad (33) }\end{array}\end{array}$ & -0.60 & $\mathbf{- 0 . 5 5}$ \\
$\begin{array}{l}\text { Height of toe pad (30) } \\
\text { Peigh }\end{array}$ & 0.48 & $\mathbf{0 . 7 0}$ \\
\hline
\end{tabular}

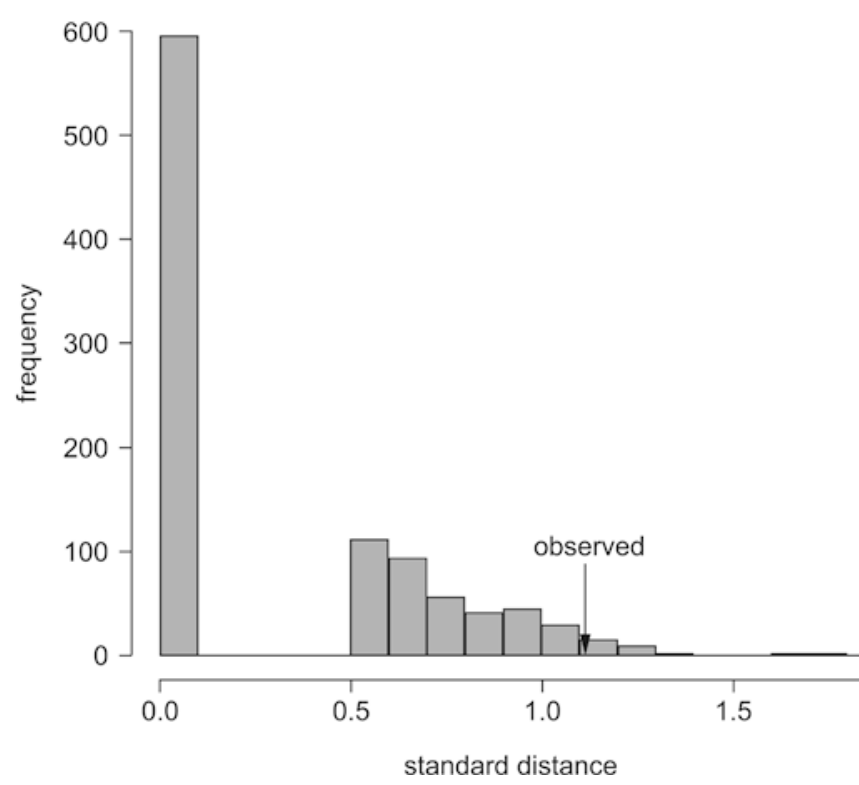

Fig. 3 Distribution of 999 standard distances between pairs of random groups, and the position of the standard distance between the needle-dwellers and the control species. The significance of the null hypothesis "the observed standard distance stems from random groups" is $P=0.028$ 
discriminant function did not originate by chance $(P=0.028)$, and the convergence seen in Fig. 4 has a significant meaning.

\section{Discussion}

Convergence may affect the general appearance of an organism, i.e. its overall morphology (e.g. the diving petrel Pelecanoides urinatrix (Pelecanidae) and the little auk Alle alle (Alcidae); Harrison 1977), or single traits (e.g. bill morphology of the American redstart Setophaga ruticilla; Keast et al. 1995). The convergence that we found in the needle-dwellers affects a few specialised traits, namely body mass and the shape of the large digital pad on the hind toe. In contrast, the phylogenetic differences between the seven lineages pertain to numerous morphological traits of all three functional complexes. Furthermore, it is possible to almost completely separate the phylogenetic lineages from each other (Fig. 2). On the other hand, the scores of the discriminant function of "needle-dwellers" and the ones of "control species" broadly overlap, though the difference between the means is significant. This shows that in the case of needle-dwelling, the morphological adaptation is subtle but meaningful.

Specialisation for foraging in conifer needles

In contrast to our expectation, we neither found convergent patterns in the morphology of the foraging apparatus nor in the flight apparatus. In our broad

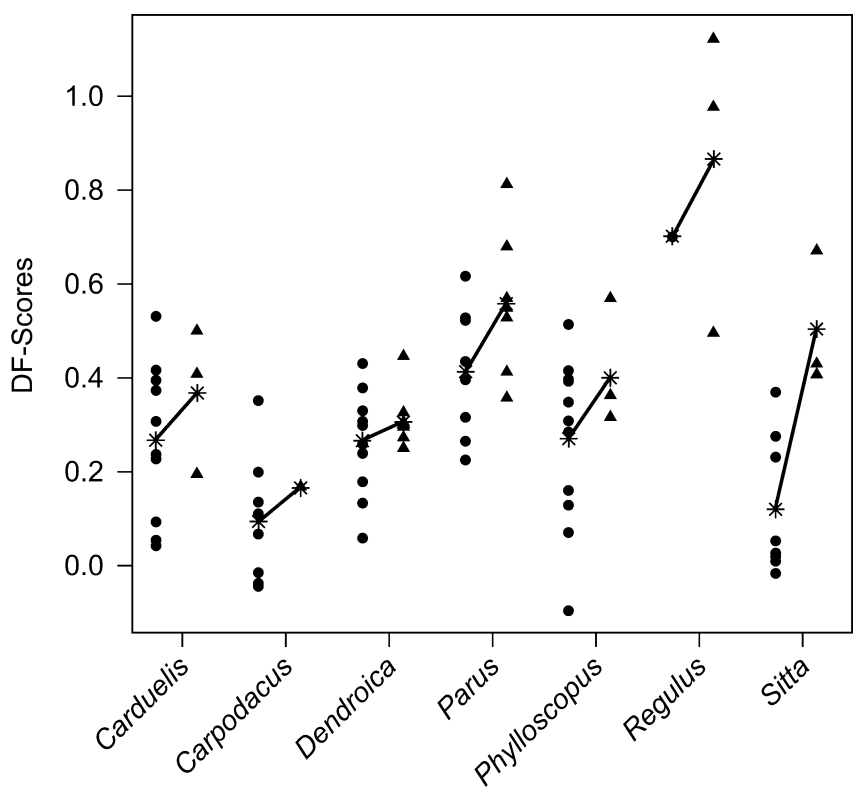

Fig. 4 The scores of the discriminant function separating needledwellers from the control species. Within each genus, the mean of the needle-dwellers lies higher than in the control species (the connections have all positive slopes). Filled circle control species, triangle needle-dweller, star mean comparative approach, only the traits with the strongest correlations became significant. Biological reasons for the absence of convergence might be phylogenetic inertia and the possibility that similar problems can be solved with different responses, as, e.g., in trunk climbers (Richardson 1942; Winkler and Bock 1976). In order to climb on trunks, birds either use a supporting tail or not. The different climbing types are reflected in different morphological adaptations. Similarly, the morphological adaptations for dwelling in coniferous needles might be divers in the feeding and flight apparatus. The feeding apparatus might correlate with the type of food taken, which is not considered in this study. Several different flight types might be used in coniferous woods: e.g. slow flights and hovering within the dense canopy, or fast flights in the open space between single trees. These different flight types may result in different morphological adaptations. However, we found a correlation between dwelling in needles and body mass as well as the morphology of the hind toe pad. The enlargement of this digital pad and the reduction of body mass are therefore homogenous trends in coniferous specialists among seven phylogenetic linages.

\section{Size}

Needle-dwellers are characterised by small body masses. In contrast to our study, Greenberg (1979) found that conifer-dwelling Dendroica species are larger than their congenerics in deciduous woods. This difference might be due to the use of different species and different methods of data analysis. Greenberg's study is based on 16 species, which included two large coniferous species (D. kirtlandi, D. castanea) that were not investigated in our study. On the other hand, among our 15 Dendroica species there are two small coniferous species (D. occidentalis, D. graciae) which are not in Greenberg's sample.

In line with our study, coniferous species tend to be smaller than deciduous species among the Phylloscopus warblers (Gaston 1974; Forstmeier et al. 2001). The latter authors developed three hypotheses to explain such a relationship: (1) Small species may show a preference for coniferous habitats because small body size allows more efficient use of foraging techniques that are advantageous in coniferous vegetation, such as hovering flight and clinging to conifer-needles, (2) larger species may prefer habitats with on average larger prey items, which are found in deciduous trees (Nyström 1991), and (3) smaller species might profit from the reduced interspecific competition in a coniferous habitat (Forstmeier et al. 2001). For our study, we favour the first hypothesis, since our "needle-dwellers" prefer foraging sites that are high off the ground, and clinging to thin substrates and hovering flight are preferred locomotion types at such high foraging sites (Morse 1976; Greenberg 1979; Perrins 1979). However, we cannot exclude the other two hypotheses. 


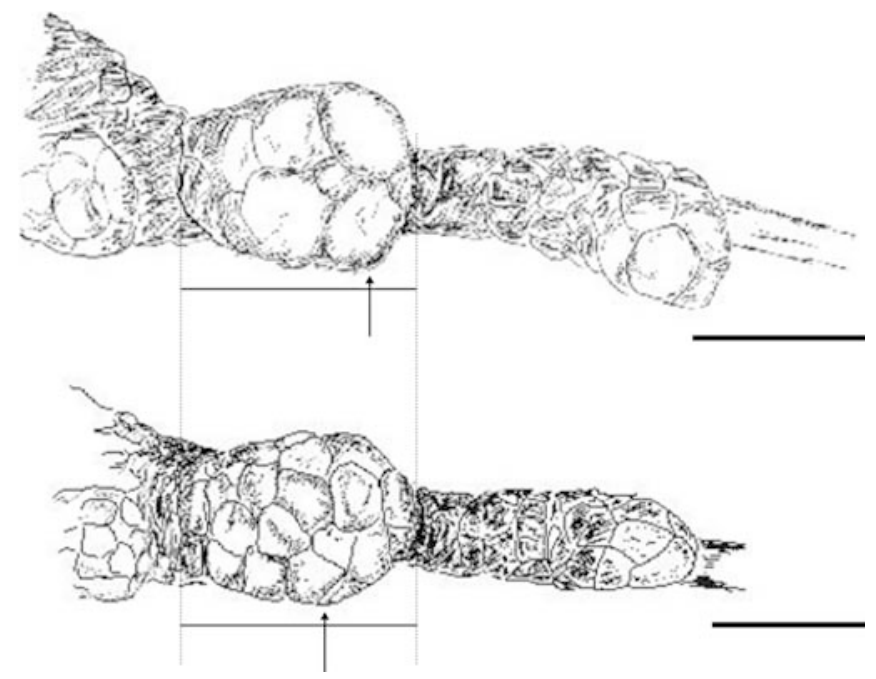

Fig. 5 Ventral view of the left hind toe of a typical needle-dweller, the goldcrest Regulus regulus (above), and the control-species firecrest Regulus ignicapillus (below). Bars $2 \mathrm{~mm}$. Arrows maximum width of the proximal toe pad which lies more distally in the goldcrest than in the firecrest. From this follows a broad distal side of the goldcrest's pad. Such a pad shape may be suited to squeeze single needles between this and the adjacent (distal) pad. Hatched lines edges of the pad

Small body mass might be an adaptation for foraging in the outermost twigs of conifers for three reasons: (1) The fine structures support only small body masses, (2) on thin and elastic substrates possible bipedal locomotion types are clinging or hanging, for both of which it is advantageous to be small (Gaston 1974), and (3) resources on the outermost twigs can also be exploited by hovering, for which it is energetically better to be small (Norberg 1990).

\section{Digital pad morphology}

We interpret the high pads with distal maximal widths (Fig. 5) to be a specialisation for clinging to a thin

Table 4 Investigated species with the number of investigated specimens, and the description of their habitat with typical tree species and foraging locality. Bold type indicate the needle- substrate such as needles where hanging by hooking with claws is difficult, while a frictional force between the needles and the foot is required. This function of the digital pad has already been suggested by Leisler and Thaler (1982), Winkler and Leisler (1985), and Keast and Saunders (1991) in birds and by Krättli (2001) in mammals (Muridae). Similarly, Lennersted (1974) found that the shapes of digital pads in passerines are highly adapted to their substrate. Pictures show that birds holding onto coniferous twigs squeeze single needles between adjacent toe pads (Winkler and Leisler 1985; Thaler-Kottek 1990; Korner-Nievergelt 2003). This, rather than a firm grip around the entire twig, seems to allow small passerines to dwell in coniferous trees. In addition, it seems plausible that a high digital pad with a distal maximal width (i.e. with a broad side towards the neighbour pad) helps to safely squeeze needles between pads. Therefore, we suggest that needle dwellers cling actively to the needles themselves, rather than only hook onto twigs as suggested by Löhrl (1974). The convergence in the digital pad morphology suggests that most birds seem to use a similar technique for pedal locomotion on coniferous needles. Our results show that convergence can affect subtle morphological traits which, nevertheless, are ecologically important.

Acknowledgements We thank the following curators for kindly providing material: M. Adams, R. van den Elzen, S. Frahnert, M. Güntert, J. Hegelbach, A. Shapoval, F. Steinheimer and R. Winkler. J. Fiebig introduced us to the helpful cherry-laurel method. Anne Thorson and Maiken Winter improved the English.

\section{Appendix}

Table 4 lists investigated species with the number of investigated specimens, and the description of their habitat with typical tree species and foraging locality

dwellers. If not otherwise indicated, information and systematics from:Baker 1997; Clement et al. 1993; Curson 1994; Harrap 1996 and Poole and Gill 1992-2002
Scientific name, English name and number Habitat description of specimens

Sitta pusilla, Brown-headed nuthatch (6)

S. pygmaea, Pygmy nuthatch (11)

S. whiteheadi, Corsican nuthatch (6)

S. azurea, Blue nuthatch (6)
Corsican pine forest, Pinus nigra

Open pine forest and pine-oak woodland, Pinus taeda, Pinus australis in winter

Ponderosa pine forest and pinyon-juniper woodland, Pinus ponderosa, Pinus jeffreyi

Lower montane forest
Description of foraging locality and codes of foraging habitat types according to Table 1

Forages in the treetops, near the tips of branches, less frequently on trunks and larger branches (1)

High up in the top and outer branches, in winter also on trunks and larger limbs (Stallcup 1968) (1)

In needle clusters and among small branches, in winter also on trunks and larger branches (1)

Middle and upper storey of tall forests (7) 
Table 4 (Contd.)

Scientific name, English name and number Habitat description of specimens

S. canadensis, Red-breasted nuthatch (9)

S. carolinensis, White-breasted nuthatch (8)

S. castanea, Chestnut-bellied nuthatch (5)

S. europea, European nuthatch (13)

S. himalayensis, White-tailed nuthatch (9)

S. magna, Giant nuthatch (4)

S. neumayer, Western rock nuthatch (6)

Parus ater, Coal tit (21)

P. cristatus, Crested tit (9)

P. gambeli, Mountain chickadee (6)

P. hudsonicus, Boreal chickadee (6)

P. melanolophus, Spot-winged tit (6)

P. rufescens, Chestnut-backed chickadee (6)

P. sclateri, Mexican chickadee (5)

P. atricapillus, Black-capped chickadee (11)

P. carolinensis, Carolina chickadee (5)

P. dichrous, Grey-crested tit (7)

P. lugubris, Sombre tit (9)

P. montanus, Willow tit (12)

P. palustris, Marsh tit (13)

P. rubidiventris, Rufous-bellied tit (8)
Coniferous forest, spruce and fir, Tsuga sp., Pinus ponderosa

Mature open deciduous forest

Open dry deciduous forest

Deciduous and mixed forest, especially oak, Quercus sp.

Oak and rhododendron forest, avoids

Abies (Martens and Eck 1995),

Quercus semercarpifolia

Pine forest

Rocky slopes, cliffs and gorges

Coniferous forest (Snow 1954)

Pure stands of conifers, especially spruce and pine (Snow 1954)

Montane coniferous woodland

Dense boreal coniferous forest, conifer specialist

Coniferous forest content also with oak (Martens and Eck 1995; Snow 1954), Abies spectabilis, Picea smithiana,

Pinus wallichiana, Cupressus torulosa, Quercus

Coniferous forest

Montane coniferous forest, prefers oak to pine

Deciduous and mixed forest (Snow 1954)

Broadleaved woodland

Wide variety of forest types (Snow 1954)

Maquis, scattered trees and bushes, olive, broadleaved woodland, farmland, oak-juniper, Quercus, Prunus, Juniperus, Juglans, Rosa, Rubus, Salix (Catsadorakis and Källander 1999; Snow 1954)

In western Europe: willow, alder, birch, in Scandinavia: coniferous forest

Mature deciduous forest (Snow 1954)

Variety of forest types, Abies spectabilis
Description of foraging locality and codes of foraging habitat types according to Table 1

In dense crowns of conifers, but may feed lower in trees $(2,3)$ On trunk and larger branches of trees, occasionally on the ground $(3,5)$

Forages in the upper half of the trees, on the trunk and smaller branches, also on the ground $(3,7)$

Trunk (3)

Mossy branches in the upper part of the tree (5)

Feeds on the limbs of trees, rather than on the trunk (2) On rocks and the ground (11) In the crown of conifers (Alatalo 1982), in the interior parts of the tree Morse 1978) $(1,2)$ In the canopy among twigs and needles (Alatalo 1982) (1, 2, 3, 8) Among the smaller branches, sometimes probing among needle clusters at the tip of branches, foliage and twigs $(1,2,6,7)$

Among the foliage and the tips of branches in the upper part of trees, larger substrates (Sabo 1980) $(1,2)$

On the trunks or in the canopy of deciduous trees, frequently found feeding in the needles of conifers $(1,3,5)$

Often high in tall conifers (Shaw and Flick 1999) (1)

Among leaves and twigs and investigates open pine cones (1)

In trees and bushes, exploring the bark from the trunk to the thinnest twigs, feeds among foliage (Sturman 1968) $(3,7,8)$

Among twigs and smaller branches $(4,5)$

At lower and middle storeys of trees, in bushes and also on the ground $(7,8,10)$

On the lower branches of trees and in the shrub layer, sometimes on the ground (8)

Favours the herb and shrub layers and the lower branches and foliage of trees (Alatalo 1982) $(6,7,8,9)$

All levels of vegetation; in the outer portions of the branches (Morse 1978), preference for bushes and lower branches of trees, in winter on the ground, $60 \%$ in branches (Suhonen et al. 1994) $(4,5,8,10)$

Largely in the canopy, also in the shrub layer $(6,7,8)$ 
Table 4 (Contd.)

Scientific name, English name and number Habitat description of specimens

P. rufonuchalis, Rufous-naped tit (9)

Regulus calendula, Ruby-crowned kinglet (7)

R. regulus, Goldcrest (11)

R. satrapa, Golden-crowned kinglet (6)

R. ignicapillus, Firecrest (10)

Phylloscopus proregulus, Palla's leaf warbler (8)

$\boldsymbol{P}$. pulcher, Orange-barred leaf warbler (10)

P. subviridis, Brook's leaf warbler (6)

P. tytleri, Tytler's leaf warbler (5)

P. bonelli, Western Bonelli's warbler (6)

P. collybita, Chiffchaff (12)

P. coronatus, Eastern crowned leaf warbler (6)

P. (inornatus) humei, Hume's leaf warbler (9)

P. inornatus, Yellow-browed warbler (7)

P. maculipennis, Ashy-throated leaf warbler (6)

P. magnirostris, Large-billed leaf warbler (6)

P. neglectus, Plain leaf warbler (6)

P. reguloides, Blyth's leaf warbler (6)

P. schwarzi, Radde's warbler (5)

$P$. sibilatrix, Wood warbler (7)

P. subaffinis (affinis), Buff-throated warbler (5)

P. tenellipes, Pale-legged leaf warbler (6)

P. trochilus, Willow warbler (10)
Spruce, fir and cedar forest, dry forest, nearly exclusively conifers (Martens and Eck 1995), open forest, Pinus wallichiana, Abies spectabilis, Picea smithiana Coniferous and mixed forest, affinity for spruce, spruce (Kessel 1998) Coniferous forest the year round (Martens and Eck 1995),Pinus, Abies Coniferous forest

Lowland broadleaved and mixed forest

Tall conifer forests with dense scrub undergrowth, no special preference (Martens and Eck 1995), Abies, Tsuga, Quercus semecarpifolia, Betula, Picea, Pinus

Conifer, or mixed conifer forest, preference for close stands (Martens and Eck 1995), Abies spectabilis, Abies densa, Betula utilis, Juniperus

Conifer forests, such as spruce, fir and pine

Coniferous forest such as blue pine and silver fir

Open deciduous woodlands, also mixed or pure coniferous stands

Open mature forests of conifers, mixed and broadleaf varieties

Mixed or deciduous open woodland

Lightly forested hills, especially silver fir, larch and pine-cedar

Open growth of broadleaved trees and shrubs

Open, mixed forests of oak and rhododendron or conifer, no discernible preferences (Martens and Eck 1995)

Open grassy glades, open spaces with fallen trees, closly associated with fast-flowing noisy mountain brooks, no preference for any forest type (Martens and Eck 1995)

Thickets of juniper and pistachio, and open degraded oak woods Mountain forests of conifer or mixed deciduous stands, high ecological plasticity (Martens

and Eck 1995)

Tall herbage, thick scrub layer

All types of forests offering continuous canopy and open or sparse vegetation

Alpine scrub and forest edges, bushes, dry habitat (Martens and Eck 1995)

Dense, often moist broadleaf and mixed forests in river valleys

Broad range of habitats, broadleaved woodland, open grass downland with scrub and bushy areas, gardens (Bibby et al. 1985)
Description of foraging locality and codes of foraging habitat types according to Table 1

In the canopy, shrub layer and on the ground $(2,8,10)$

According to Sabo (1980) higher up in the canopy than $R$. satrapa (1) Canopy, rather tit-like among needles (Alatalo 1982) (1) Canopy, among needles, conifer specialist using fine substrate (Sabot 1980) (1)

Canopy $(5,7)$

In canopy, goldcrest-like on the outside of trees, also often found in the bottom stratum., among the low shrubbery at the edge of the forest (Martens and Eck 1995) $(1,2)$

In tree canopy, among foliage

$(1,2)$

Canopy, among foliage $(1,2)$

Outer boughs of fir or pine trees, or amongst the branches of dwarf willow, arboreal deciduous/conifers (Gaston 1974) $(1,2,4)$

In foliage $(2,6)$

In foliage, from ground level up to tree canopy $(6,7,10)$ Arboreal, but forages at all levels $(6,7,8)$

At all levels, also shrubs, among foliage (Gross and Price 2000) $(6,7,8)$

At all levels of the trees, among foliage $(4,5,8)$

Strongly arboreal $(6,7,8)$

Lower branches of firs, undergrowth, among low vegetation on grassy banks $(2,7)$

Essentially arboreal $(6,7,8)$

Canopy, secondary scrub and bush layer $(4,6,8)$

On the ground $(8,10)$

In tree canopies (7)

On the ground, thick vegetation

$(8,9,10)$

Middle and lower storey

of forest $(6,7,8)$

In foliage, (Alatalo 1982), from ground level up to tree canopy $(4,6,7,10)$ 
Table 4 (Contd.)

Scientific name, English name and number of specimens

Habitat description

Description of foraging locality and codes of foraging habitat types according to Table 1

\author{
C. flavirostris, Twite (8) \\ C. hornemanni, Arctic redpoll (5)
}

C. notata, Black-headed siskin (4) C. psaltria, Dark-backed goldfinch, Lesser goldfinch (6)

C. spinoides, Himalayan greenfinch (5)

Carpodacus cassinii, Cassin's finch (6)

C. erythrinus, Common rosefinch (8)

C. mexicanus, House finch (7)

C. nipalensis, Dark rosefinch (6)

C. pulcherrimus, Beautiful rosefinch (12)

C. puniceus, Red-breasted rosefinch (4)

C. purpureus, Purple finch (7)

C. roseus, Pallas's rosefinch (5)

C. rubicilla, Caucasian great rosefinch (5)

Dendroica fusca, Blackburnian warbler (5)

D. graciae, Grace's warbler (5)

D. magnolia, Magnolia warbler (12)

D. occidentalis, Hermit warbler (5)
Open wooded areas of Pinus insularis, Pinus insularis

Conifers, mainly spruce, mixed forest

Conifers, chiefly spruce, also in alders, larch and beech

Forests to open country

Heathland with scattered trees

Variety of habitats

Low forests, orchards, and gardens

Open subarctic, largely coniferous forest

Open hillsides, moorland, open terrain or cliffs

High arctic, tundra, ravines, slopes, dwarf birch and willow thickets

Conifer and oak forest

Dry, open country, brush, woodland or roadside edges, Pinus-Juniperus,Populus fremontii, Salix nigra

Oak, rhododendron or conifer forest, no preference for either coniferous or broadleaved trees (Martens and Eck 1995)

Open conifer forest, Pinus contorta, $P$. ponderosa

Willow or tamarisks, thickets or patches of scrub or bushes, pines and firs nearby (Martens and Eck 1995)

Suburban towns, villages, farmland, desert, grassland

Mixed oak or conifer and rhododendron forest, Rhododendron (Martens and Eck 1995)

Rhododendron, buckthorn, oak and juniper scrub and forest edges, coniferous zone (Martens

and Eck 1995)

Alpine meadows, plateaus, dry valleys, rock screes, cliffs and glaciers

Conifer forest

Conifer, birch and cedar forest

High-altitude valleys and plateaus of open boulder or rock-strewn areas

Mature coniferous forest and mixed forest, hemlock

Pine-oak forest, Ponderosa pine, yellow pine

Coniferous forest, young stands of spruce, balsam fir or hemlock, Pinus strobus

Tall mature coniferous forest, Douglas fir, Abies, Picea
Canopy $(1,2,13)$

Feeds on a variety of seeds $(1,4,6,10)$

High up in conifers, also on ground $(1,2)$

Mostly on the ground, also high

in trees $(7,9,10)$

Ground $(9,10)$

On plants or on the ground (9)

Ground-loving forager $(5,9,10)$

On alders or birch catkins, plants and on the ground; feeds in trees and shrubs at ends of small branches, $96 \%$ in vegetation, $5 \%$ on ground $(4,8,9,10)$

Ground, or on vegetation $(9,10,11)$

Feeds actively in trees, often at extremities, searches stems and crotches for insects, on the ground (8)

Small plants, pines (9)

Feeds on a variety of seeds from trees, sunflowers and on the ground $(4,9)$

At the top of pines or alders $(6,7,8)$

Feeds either in the top of tree or on the ground, removes seeds from cones and insects from conifer foliage (Torgersen et al. 1990) $(1,10)$

Plant and tree seeds and buds, bamboo, crops $(7,8,9)$

Spends more time on ground than other Carpodacus (10)

Feeds on small seeds, also nectar from rhododendron $(8,9)$

Low down or on the ground $(8,10)$

Ground (10)

Outer portions of tree branches, bushes or on the ground $(2,8,10)$ In trees, bushes or on the ground $(2,7,9)$

Feeds on the ground or in bushes $(8,10)$

High in canopy, on small limbs (Morse 1968) (1, 13)

Treetops, high levels $(1,6,13)$

Low to middle levels, midstory (Sabo 1980), on small limbs (Morse 1968), on outer ends of branches at midtree heights in dense conifer foliage, also in dense broadleaved shrubs $(1,2,13)$

Treetops, concentrates activity on foliage and twigs (1) 
Table 4 (Contd.)

Scientific name, English name and number Habitat description of specimens

D. pinus, Pine warbler (8)

D. tigrina, Cape May warbler (6)

D. townsendi, Townsend's warbler (6)

D. caerulescens, Black-throated blue warbler (7)

D. cerulea, Cerulean warbler (6)

D. coronata, Yellow-rumped warbler, Myrtle (9)

D. palmarum, Palm warbler (7)

D. pensylvanica, Chestnut-sided warbler (5)

D. petechia, Yellow warbler (10)

D. striata, Blackpoll warbler (5)

D. virens, Black-throated green warbler (7)

Parula americana, Northern parula (8)

$P$. pitiayumi, Tropical parula,

Olive-backed warbler (7)

P. superciliosa, Crescent-chested warbler (3)
Pine forest, exclusively pines, Pinus taeda

Black spruce forest, black spruce

Tall mature coniferous forest, especially fir, Picea glauca (Matsuoka et al. 1997), Pseudotsuga menziensii (Marzluff et al. 1996)

Mature deciduous and mixed woodland

Mature deciduous, tall trees, occasionally mixed woods

Coniferous or mixed forest or woodland

Bogs, especially spruce bogs, but avoids dense forest, Picea mariana, Larix laricina

Young second-growth deciduous forest, brushy thickets

Open, often damp habitats such as alder and willow thickets

Spruce forest, Picea mariana, Abies balsamea

Open coniferous and mixed forest

Deciduous or coniferous forest, Usnea lichen Deciduous and gallery forest, oak woodland with epiphytes, ball moss Tillsandia baileyi

Pine-oak and cloud forest
Description of foraging locality and codes of foraging habitat types according to Table 1
Distal half of limb and tips of foliage (Ficken et al. 1968), foraging observations: $43 \%$ in pine foliage, $30 \%$ bark, $13 \%$ air $(1,2,10)$

High in the trees, in rainy weather in thickets of willows (MacArthur 1958) $(1,13)$ Treetop, on migration often near the ground (Tramer and Kemp 1982) $(1,13)$

In the understory and on the ground, lower to mid strata $(7,8)$ Mainly in the canopy, takes food from leaf bases and foliage $(4,13)$

Mostly at high levels, also on trunks and branches (Sabo 1980), on small limbs (Morse 1968), often from lower branches, often clings to vertical bark $(6,7,13)$

Ground $(77 \%$ on ground, $15 \%$ in air, $9 \%$ on broad leaves (Lack and Lack 1972 in Poole and Gill 1992-2002) (10)

At low to middle levels in shrubs and the lower branches of tall trees (5)

From the ground to the treetops, never on ground, on small limbs $(6,7,10,13)$

At mid to high level, midstorey (Sabo 1980), inner branches (Morse 1979), often seen probing in closed buds on twigs $(2,13)$

All levels (Maurer and Whitmore 1981; Tramer and Kemp 1982; Sabo 1980), small limbs (Morse 1968) $(6,7,13)$

Treetops (6)

Mainly in the outer branches of the canopy, tends to forage near ends of branches of twigs $(4,6)$ Middle to high levels $(4,5,6)$

\section{References}

Alatalo RV (1982) Multidimensional foraging niche organization of foliage-gleaning birds in northern Finland. Ornis Scand 13:56-71

Bailey RC, Byrnes J (1990) A new, old method for assessing measurement error in both univariate and multivariate morphometric studies. Syst Zool 39:124-130

Baker K (1997) Warblers of Europe, Asia and North Africa. Princeton University Press, Princeton, N.J.

Bibby CJ, Phillips BN, Seddon AJE (1985) Birds of restocked conifer plantations in wales. J Appl Ecol 22:619-633

Catsadorakis G, Källander H (1999) Densities, habitat and breeding parameters of the Sombre tit Parus lugubris in Prespa National Park, Greece. Bird Study 46:373-375
Clement P, Harris A, Davis J (1993) Finches and sparrows. Princeton University Press, Princeton, N.J.

Cody ML, Mooney HA (1978) Convergence versus nonconvergence in Mediterranean-climate ecosystems. Annu Rev Ecol Syst 9:265-321

Curson J (1994) New World warblers. Black, London

Dunning JB (1992) CRC handbook of avian body masses. CRC, London

Feduccia A (1993) Evidence from claw geometry indicating arboreal habits of Archeaeoptryx Science 259:790-793

Ficken RW, Ficken MS, Morse DH (1968) Competition and character displacement in two sympatric pine-dwelling warblers (Dendroica, Parulidae). Evolution 22:307-314

Forstmeier W, Bourski OV, Leisler B (2001) Habitat choice in Phylloscopus warblers: the role of morphology, phylogeny and competition. Oecologia 128:566-576 
Futuyma DJ (1998) Evolutionary biology. Sinauer, Sunderland, Mass.

Gaston AJ (1974) Adaptation in the genus Phylloscopus. Ibis 116:432-450

Grant PR, Grant BR, Smith JNM, Abbott IJ, Abbott LK (1976) Darwin's finches: Population variation and natural selection. Proc Natl Acad Sci 73:257-261

Greenberg R (1979) Body size, breeding habitat, and winter exploitation systems in Dendroica. Auk 96:756-766

Gross SJ, Price TD (2000) Determinants of the northern and southern range limits of a warbler. J Biogeo 27:869-878

Harrap S, Quinn D (1996) Tits, nuthatches and treecreepers. Black, London

Harrison CJO (1977) The limb osteology of the diving petrels and the little auk as evidence of the retention of characters in morphologically convergent species. Ardea 65:43-52

Hespenheide HA (1973) Ecological inferences from morphological data. Annu Rev Ecol Syst 4:213-229

Karr JR, James, FC (1975) Eco-morphological configurations and convergent evolution in species and communities. In: Cody ML, Diamond JM (eds) Ecology and evolution of communities. Belknap Press of Harvard University, Cambridge, Mass., pp 258-291

Keast A, Saunders S (1991) Ecomorphology of the North American ruby-crowned Regulus calendula and golden-crowned $R$. satrapa kinglets. Auk 108:880-888

Keast A, Pearce L, Saunders S (1995) How convergent is the American redstart Setophaga ruticilla (Parulinae) with flycatchers (Tyrannidae) in morphology and feeding behaviour? Auk 112:310-325

Kessel B (1998) Habitat characteristics of some passerine birds in western North American Taiga. University of Alaska Press, Fairbanks, Alaska

Korner-Nievergelt F (2003) Relations of substrate use and morphology: Morphological convergence in conifer-dwelling passerines (Passeriformer, Aves). PhD Thesis, University of Zurich

Krättli H (2001) Struktur und Funktion des Extremitäteninteguments bei einheimischen Mäuseartigen (Muridae, Rodentia). PhD Thesis, University of Zurich

Leisler B, Thaler E (1982) Differences in morphology and foraging behaviour in the goldcrest Regulus regulus and firecrest $R$. ignicapillus. Ann Zool Fenn 19:277-284

Leisler B, Winkler H (1985) Ecomorphology. Curr Ornithol 2:155186

Leisler B, Winkler H (1991) Ergebnisse und Konzepte ökomorphologischer Untersuchungen an Vögeln. J Ornithol 132:373425

Leisler B, Winkler H (2001) Morphological convergence in papyrus dwelling passerines. Ostrich 15:24-29

Leisler B, Winkler H (2003) Morphological consequences of migration in passerines. In: Berthold $\mathrm{P}$, Gwinner E, Sonnenschein E (eds) Avian migration. Springer, Berlin Heidelberg New York, pp 175-186

Leisler B, Ley HW, Winkler H (1989) Habitat, behaviour and morphology of Acrocephlus warblers: an integrated analysis. Ornis Scand 20:181-186

Lennersted I (1974) Pads and papillae on the feet of nine passerine species. Ornis Scand 5:103-111

Löhrl H (1974) Die Tannenmeise. Ziemsen, Wittenberg Lutherstadt

MacArthur RH (1958) Population ecology of some warblers of northeastern coniferous forests. Ecology 39:599-619

Martens J, Eck S (1995) Towards an ornithology of the Himalayas: Systematics, ecology and vocalisations of Nepal birds. Bonn Zool Monogr, Bonn

Marzluff JM, Heinrich B, Marzluff CS (1996) Raven roosts are mobile information centres. Anim Behav 51:89-103

Matsuoka SM, Handel CM, Roby DD, Thomas DL (1997) The relative importance of nesting and foraging sites in selection of breeding territories by Townsend's warbler. Auk 114:657-667
Maurer BA, Whitmore RC (1981) Foraging of five bird species in two forests with different vegetation structure. Wilson Bull 93:478-490

Morse DH (1968) A quantitative study of male and female sprucewoods warblers. Ecology 49:779-784

Morse DH (1976) Variables affecting the density and territory size of breeding spruce-woods warblers. Ecology 57:290-301

Morse DH (1978) Structure and foraging patterns of flocks of tits and associated species in an English woodland during the winter. Ibis 120:298-312

Morse DH (1979) Habitat use by the Blackpoll warbler. Wilson Bull 91:234-243

Norberg UM (1990) Vertebrate flight. Springer, Berlin Heidelberg New York

Nyström KGK (1991) On sex-specific foraging behaviour in the willow warbler Phylloscopus trochilus. Can J Zool 69:462-470

Perrins CM (1979) British tits. Collins, London

Poole A \& Gill F (1992-2002) The birds of North America. The Birds of North America, Philadelphia, Pa.

R Development Core Team (2002) R: a language and environment for statistical computing. R Foundation for Statistical Computing, Vienna, Austria. http://www.R-project.org. Cited 9 Feb 2004

Richardson F (1942) Adaptive modifications for tree-trunk foraging in birds. Univ Calif Publ Zool 46:317-368

Ricklefs RE, Miles DB (1994) Ecological and evolutionary inferences from morpholoy: an ecological perspective. In: Wainwright PC, Reilly SM (eds) Ecological morphology, integrative organismal biology. University of Chicago Press, Chicago, pp $13-41$

Sabo SR (1980) Niche and habitat relations in subalpine bird communities of the White Mountains of New Hampshire. Ecol Monogr 50:241-259

Schluter D (1986) Tests for similarity and convergence of finch community. Ecology 67:1073-1085

Shaw D, Flick C (1999) Are resident songbirds stratified within the canopy of a coniferous old-growth forest? Selbyana 20:324-331

Sibley CG, Ahlquist JE (1983) Phylogeny and classification of birds based on the data of DNA-DNA hybridization. Curr Ornithol 1:245-292

Snow DW (1954) The habitats of Eurasian tits (Parus spp.). Ibis 96:565-585

Stallcup PL (1968) Spatio-temporal relationships of nuthatches and woodpeckers in Ponderosa pine forests of colorado. Ecology 49:832-843

Sturman WA (1968) Description and analysis of breeding habitats of the chickadees, Parus atricapillus and P. rufescens. Ecology 49:418-431

Suhonen J, Alatalo RV, Gustafsson L (1994) Evolution of foraging ecology in Fennoscandian tits Parus spp. Proc R Soc Lond B 258:127-131

Thaler-Kottek E (1990) Die Goldähnchen. Ziemsen, Wittenberg Lutherstadt

Torgersen TR, Mason RR, Campbell RW (1990) Predation by birds and ants on two forest insect pests in the Pacific northwest. Studies Avian Biol 13:14-19

Tramer EJ, Kemp TR (1982) Notes on migrants wintering at Monteverde, Costa Rica. Wilson Bull 94:350-354

Wechsler K, Fiebig J, Henche A, Plackinger U, Rauer-Gömann M, Scheidt H (2001) Über das Weichen trockengefallener Alkoholund Formalinpräparate, Herbarblätter und von Tapagewebe. Praparator 47:15-31

Winkler H, Bock W J (1976) Analyse der Kräfteverhältnisse bei Klettervögeln. J Ornithol 117:397-418

Winkler H, Leisler B (1985) Morphological aspects of habitat selection in birds. In: Cody $M$ (ed) Habitat selection in birds: 415-434. Academic Press, London 